\title{
Painful subungual glomus tumour of the left thumb
}

\author{
Pravit Kitidumrongsook, ${ }^{1}$ Pobe Luangjarmekorn, ${ }^{1}$ Adisorn Patradul, ${ }^{1}$ \\ Sittisak Honsawek ${ }^{1,2}$
}

${ }^{1}$ Department of Orthopaedics, Faculty of Medicine,

Chulalongkorn University, King Chulalongkorn Memorial Hospital, Bangkok, Thailand ${ }^{2}$ Department of Biochemistry, Faculty of Medicine,

Chulalongkorn University, King Chulalongkorn Memorial Hospital, Bangkok, Thailand

\section{Correspondence to}

Professor Sittisak Honsawek, sittisak.h@chula.ac.th

\section{DESCRIPTION}

A 32-year-old woman presented with a 1-year history of severe paroxysmal pain, point tenderness and sensitivity to cold in her left thumb. On examination, a faint bluish lesion in the middle, radial subungual region of the left thumb was observed (figure 1A). Love's pin test was positive when pressure was applied with a pencil tip or pinhead on the lesion. She experienced excruciating pain, whereas pressure applied slightly to one side of it elicited no pain. We suspected a vascular tumour and exploratory surgery was performed by a dorsal, transungual approach. After complete removal of the nail plate, a reddish-blue lesion was evident at the nail bed (figure 1B). Histopathological examination demonstrated an encapsulated, well-defined mass to be a glomus tumour, which comprised multiple vascular channels lined by endothelial cells and aggregates of uniform round or slightly polygonal cells with sharp cellular borders and eosinophilic cytoplasm. The perivascular myoid tumour cells were embedded in the collagenous stroma as solid sheets or a thin layer around vascular spaces (figure 1C). The patient's symptoms including exquisite pain, point tenderness and cold hypersensitivity resolved completely within several weeks after surgical excision. There was no recurrence of the tumour at 2 years' follow-up.
A glomus tumour is an enigmatic, painful tumour that is rarely seen and represents a proliferation of the normal capsular-neural glomus apparatus. ${ }^{1}$ The classic history is of paroxysmal pain, focal tenderness and cold sensitivity. The mechanism of pain may be attributed to contraction of myofilaments in response to temperature changes, leading to an increase in intracapsular pressure. ${ }^{2}$ The typical presentation is a solitary nodule in the subungual or periungual area of the distal phalanx. Clinical tests, such as Love's pin test, cold sensitivity test and Hildreth's test, are useful in diagnosing glomus tumour. ${ }^{3}$ A positive Love's pin test consists of applying pressure over the suspected area with a pinhead, which elicits exquisite localised pain. Cold sensitivity test provokes increased pain when the finger is exposed to cold water or an ice cube. Hildreth's test produces a reduction in pain and tenderness after applying a tourniquet proximal to the lesion. Once the pressure cuff is released, there is a sudden return of pain to the affected area. The differential diagnosis includes subungual exostosis, neuroma, ganglion, inclusion cyst and melanoma. ${ }^{4}$ Painful skin lesions also include blue rubber bleb naevus, eccrine spiradenoma, neuroma, angiolipoma, leiomyoma, dermatofibroma, squamous cell carcinoma and other malignancies. ${ }^{5}$ The primary treatment of choice is surgical removal. When

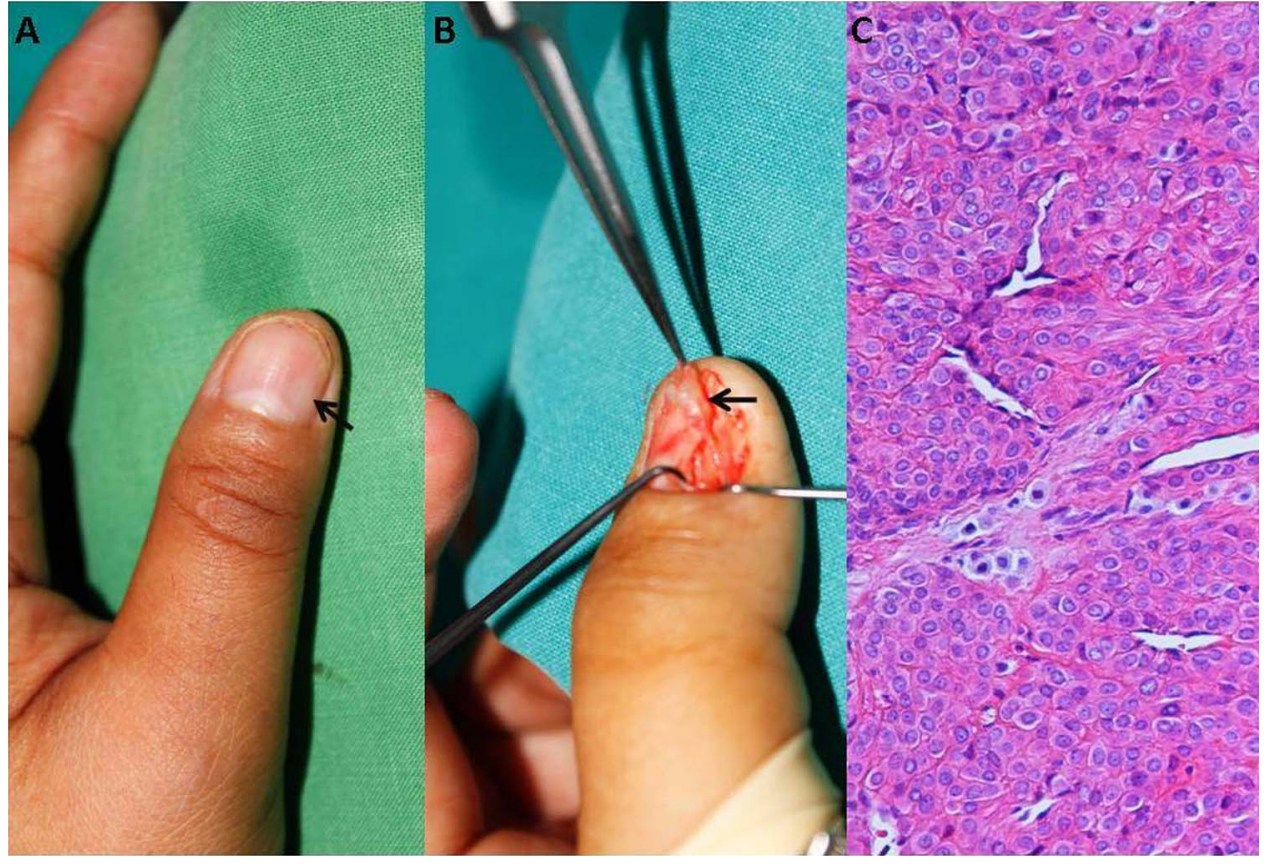

Figure 1 (A) The bluish discolouration of subungual glomus tumor of the left thumb (arrow). (B) Intraoperative photograph of the glomus tumor in its in situ location (arrow). (C) Histopathology revealed multiple vascular channels lined by endothelial cells and aggregates of round cells with darkly stained round to ovoid nuclei and eosinophilic cytoplasm (H\&E stain, $\times 400)$. 
making a differential diagnosis of unexplained excruciating pain, temperature sensitivity and severe point tenderness in the finger, glomus tumour must be taken into account.

\section{Learning points}

Glomus tumour is an enigmatic, painful tumour representing a proliferation of the normal capsular-neural glomus apparatus.

- The classic history of glomus tumour is excruciating paroxysmal pain, severe point tenderness, and cold sensitivity.

- The mechanism of pain may be attributed to contraction of myofilaments in response to temperature changes, leading to an increase in intracapsular pressure.
Acknowledgements The authors would like to thank Dr Voranuch Thanakit and Mr Preecha Ruangvejvorachai for their technical assistance on histopathological examination.

Contributors All the authors contributed in preparing and reviewing the manuscript. PK and SH contributed to history taking and reviewing the manuscript.

Competing interests None.

Patient consent Obtained.

Provenance and peer review Not commissioned; externally peer reviewed.

\section{REFERENCES}

1 McDermott EM, Weiss AP. Glomus tumors. J Hand Surg Am 2006;31:1397-400.

2 Samaniego E, Crespo A, Sanz A. Key diagnostic features and treatment of subungual glomus tumor. Actas Dermosifiliogr 2009;100:875-82.

3 Hazani R, Houle JM, Kasdan ML, et al. Glomus tumors of the hand. Eplasty 2008;8:e48.

4 Smalberger GJ, Suszko JW, Khachemoune A. Painful growth on right index finger. Subungual glomus tumor. Dermatol Online J 2011;17:12.

5 Naversen DN, Trask DM, Watson FH, et al. Painful tumors of the skin: 'LEND AN EGG' J Am Acad Dermatol 1993:28:298-300.

Copyright 2013 BMJ Publishing Group. All rights reserved. For permission to reuse any of this content visit http://group.bmj.com/group/rights-licensing/permissions.

BMJ Case Report Fellows may re-use this article for personal use and teaching without any further permission.

Become a Fellow of BMJ Case Reports today and you can:

- Submit as many cases as you like

- Enjoy fast sympathetic peer review and rapid publication of accepted articles

- Access all the published articles

- Re-use any of the published material for personal use and teaching without further permission

For information on Institutional Fellowships contact consortiasales@bmjgroup.com

Visit casereports.bmj.com for more articles like this and to become a Fellow 